\title{
INDEX ACCORDING TO SUBJECTS
}

[The numbers refer to pages.]

Algebra . . - Kermack, W. O. and McCrea, W. H., 220 : Turnbull, H. W., 33, 256 : Wilson, R. 158 : Williamson, J., 240.

Analysis . . . Copson, E. T., 108: Ferrar, W. L., 71: Mursi, M., 101: Prasad, B. N., 129: Whittaker, J. M., 1. 111.

Automorphic Functions Mursi, M., 101.

Bessel Functions . MacRobert, T. M., 26.

Combinatory Analysis . Aitken, A. C., 164.

Differential Equations . Ferrar, W. L., 71: Kermack, W. O., and MeCrea, W. H., 205, 220 : Ruse, H. S., 135, 181 : Whittaker, E. T., 189.

Fourier Series and . MacRobert, T. M., 26: Prasad, B. :N., 119: Whittaker, Integrals J. M., 1.

Geometry, Algebraic - Baker, H. F., 55 : Blakey, J., 168: Richmond, H. W., 92.

Interpolation - - Lidstone, G. J., 16.

Invariants - - Baker, H. F., 55 : Das Gupta, P. N., and Turnbull, H. W., $61 .$.

Lugendre Functions - MacRobert, T. M., 20.

Numbers, Theory of . Richmond, H. W., 92.

Obituary Notices $\quad$ - 265, 268.

Spherical Trigonometry Sen, R. N., 6.

Topology . . . . Birkhoff, G. 1., 83.

Relativity . . . McCrea, W. H., 158: McVittie, G. C., 140 : Sen, R. N., 252. 


\section{The following Presents to the Library have been received, for which the Society tenders its grateful thanks.}

1. Abhandlungen aus dem Mathematischen Seminar der Hamburgischen Universität.

2. Acta Universitatis Asiae Mediae.

3. Ansis da Faculdade de Sciências do Porto.

4. Annales de la Faculté des Sciences de Marseille.

5. Annales de la Faculté des Sciences de l'Université de Toulouse.

6 Annales Scientifiques des Institutions Mathematiques Savantes de l'Ukraine.

7. Annales Scientifiques de L'Université de Jassy.

8. Annals of Mathematical Statistics.

9. Annals of Mathematics.

10. Nieuw Archief voor Wiskunde.

11. Arkiv für Matematik, Astronomi Och Fysik.

12. Boletin de Seminario Matemático Argentino.

13. Bulletin of the American Mathematical Society.

14. Bulletin de Mathématiques et de Phisique Pures et appliquèe de l' École Polytechnique de Bucarest.

15. Bulletin of the Calcutta Mathematical Society.

16. Bulletin de la Société Mathématique de France.

17. Bulletin de la Société Physico-Mathématique de Kasan.

18 Bulletin Mathématique de la Société Roumaine des Sciences.

19. Communications de la Société Mathématique de Kharkow.

20. Contribucion al Estudio de las Ciencias Fisicas y Matematicas.

21. Fundamenta Mathematicae.

22. The Mathematical Gazette.

23. Jahresbericht der Deutschen Mathematiker-Vereinigung.

24. American Journal of Mathematics.

25. Journal of the Faculty of Science, Imperial University of Tokyo.

26. Journal of the Indian Mathematical Society.

27. Japanese Journal of Mathematics.

28. Journal of Mathematics and Physics, Massachusetts Institute of T'echnology.

29. Journal de la Société Physico-Mathématique de Léningrade.

30. Kansas University Science Bulletin.

31. Lunds Universitets Ärsskrift.

32. Mathematica (Bucarest).

33. Memorias Cientificas de la Direccion de Montes y Minas.

34. Memoirs of the Ryojun College of Engineering.

35. Mémoires de la Société Royale des Sciences de Liège.

36. Memoirs of the Faculty of Science and Agriculture, Taihoku Imperial University.

37. Memorias de la Real Academia de Ciencias exactas, fisicas y naturales (Madrid).

38. Memoirs and Proceedings of the Manchester Literary and Philosophical Society.

39. Monatshefte für Mathematik und Physik.

40. Nachrichten von der Gesellschaft der Wissenschaften zu Göttingen (Mathematischphysikalische Klasse).

41. Nachrichten von der Gesellschaft der Wissenschaften zu Göttingen (Geschäftliche Mitteilungen).

42. Wiskundige Opgaven met de Oplossingen.

43. Proceedings of the American Philosophical Society.

44. Proceedings of the Cambridge Philosophical Society. 
45. Proceedings of the Leeds Philosophical and Literary Society.

46. Proceedings of the Iondon Mathematical Society.

47. Proceedings of the National Academy of Sciences.

48. Proceedings of the Physico-Mathematical Society of Japan.

49. Proceedings of the Royal Society of Edinburgh.

50. Publications de la Faculté des Sciences de l'Université Masaryk.

51. Publications de l'Institut de Mathématiques de l'Université de Strasbourg.

52. Publications du Laboratoire d'Astronomie et de Géodésie de l'Université dè Louvain.

53. Publications from the Massachusetts Institute of Technology.

54. Publications of the U.S. Coast and Geodetic Survey.

55. Rendiconti del Circolo Matematico di Palermo.

56. Rendiconti del Seminario Matematico e Fisico di Milano.

57. Rendiconti del Seminario Matematico delle R. Universita di Padova.

58. Revista de la Real Academia de Ciencias de Madrid.

59. Revue Semestrielle des Publications Mathematiques.

60. Schola et Vita.

61. Science Reports of the Tôhoku Imperial University.

62. Sitzungsberichte der Königlich Bayerischen Akademie der Wissenschaften Mathematisch-Physikalische Klasse zu München.

63. Sitzungsberichte (Wien).

64. Studia Mathematica.

65. Sydney University Reprints.

66. Smithsonian Publications.

67. Matematisk Tidssk rift.

68. The Tôhoku Mathematical Journal.

69. Transactions of the Actuarial Society of America.

70. The University of Missouri Studies.

71. Verhandlungen der Naturforschenden: Gesellschaft in Basel.

72. Vierteljahrschrift der Naturforschenden Gesellschaft in Zürich.

73. Warsaw Prace Matematyczno-Fizyczne.

74. Geometrische Konfigurationem: Dr FrIedrica Levi.

75. Nociones de Cálculo Differentiae Absoluto: D. José Maria Plano y Freyre.

76. Platons Verhältnis zur Mathematik: Dr Seth Demel.

77. Papers on Determinants: Sir Thomas Muir.

78. Nuevas Formulus de Transformacion de Coordenadas: Jose IsaAc Corral.

79. Das Wesen der Materie und der Aufbau der Atome: G. WEBer.

80. Occupational Mortality Ratings: Actuarial Society of AMErica.

81. Joint Occupation Study: ACruarial Societry gf America.

82. Beweis des Fermat'schen Lehrfatzes $A^{n}+B^{n}=C^{n}$ : Dr A. Kellermans.

83. The Identity Theory: Blamey Stevens.

84. Comptes-Rendus I Congrès des Mathématiciens des Pays Slaves, Warsaw 1929. 